\title{
The Dietary Intakes of Calcium and Bone Health Related Nutrients Among Individuals with and without Spinal Cord Injury
}

\author{
Masae Miyatani ${ }^{1, *}$, B. Cathy Craven $^{1,2}$, Eva Loewenberger ${ }^{4}$, Colleen F. McGillivray ${ }^{1,2}$ and \\ Jonathan D. Adachi ${ }^{5,6}$
}

${ }^{1}$ Toronto Rehabilitation Institute - University Health Network, Lyndhurst Centre, Toronto, Ontario, Canada

${ }^{2}$ University of Toronto, Department of Medicine, Division of Physiatry, Toronto, Ontario, Canada

${ }^{4}$ Region of Peel Public Health, Mississauga, Ontario, Canada

${ }^{5}$ St Joseph's Hospital Hamilton, Ontario, Canada

${ }^{6}$ McMaster University, Department of Medicine, Division of Rheumatology, Canada

\begin{abstract}
Objectives: The purposes of this observational study were to: 1) describe and compare the intakes of nutrients related to bone health among a group of individuals with traumatic spinal cord injury $(\mathrm{SCl})$ versus a group of age, gender and weight matched non-SCl peers; and 2) contrast the participant's nutrient intakes against current dietary reference intakes (DRIs).

Methods: Consenting participants included: 87 individuals with SCI (C2-T10 AIS A-D) aged 18-68 years and 85 non-SCI individuals. Participants' nutrient intakes were determined using a 24-hour dietary recall. Participants were grouped by gender, age (19-30yrs, 31-50yrs, 51-68yrs), and impairment (SCl and non-SCl). Additionally, the nutrient intakes were contrasted with the DRIsparameters.

Results: The range for mean calcium intakes across all age strata was $870-1087 \mathrm{mg} /$ day for SCl men and $848-$ $1087 \mathrm{mg} /$ day for $\mathrm{SCl}$ women. The range for mean calcium intakes of the non-SCl participants were similar (men: $900-$ 909mg/day; women: $796-1160 \mathrm{mg} /$ day). The majority of SCl and non-SCI men (64 - 86\% of participants) in all age groups and $\mathrm{SCl}$ and non-SCl women in the $52-68$ yrs group (72 and $73 \%$ of participants) did not meet the DRIs recommendation for calcium.. Additionally many participants did not meet the DRIs recommendation for magnesium (38$55 \%)$ and potassium (71-95\%) regardless of gender and impairment. The majority $(60-70 \%)$ of participants consumed excessive amounts of sodium with the exception of non-SCl women.

Conclusions: Dietary calcium intakes among $\mathrm{SCl}$ and non-SCl participants were not significantly different from each other. However, the dietary calcium intakes of both impairment groups were less than the recommended DRIs; $\mathrm{SCI}$ men and women are a target for nutritional interventions based on their calcium, magnesium potassium and sodium intakes.
\end{abstract}

Keywords: Calcium, 24 hour recall, spinal cord injury, dietary assessment, osteoporosis.

\section{INTRODUCTION}

Patients with motor complete spinal cord injury (SCl) experience a rapid 3\%-4\% per month decline in regional bone mass of the hip and knee region within the first 12-16 months after injury [1-5]. This decline in bone mineral density (BMD) of the hip and knee region is predominantly peri-articular with relative preservation of cortical bone and reduced trabecular volume due to endosteal resorption [6-8]. During the period of excessive bone resorption early after $\mathrm{SCl}$, specific metabolic alterations occur including increased urinary calcium, nitrogen, hydroxyproline, and zinc excretion. Hypercalciuria (urinary calcium excretion of $>250 \mathrm{mg} /$ day for women or $>300 \mathrm{mg} /$ day for men) [9], is a metabolic disorder that contributes to calcium stone formation in people with $\mathrm{SCl}$ [10], and may be

*Address correspondence to this author at the Lyndhurst Centre, Toronto Rehabilitation Institute-UHN, 520 Sutherland Drive, Toronto, Ontario, M4G 3V9, Canada; Tel: +1-416-597-3422 (ex.6304); Fax: +1-416-425-9923;

E-mail: masae.miyatani@uhn.ca associated with the early rapid decline in bone mass [11 12]. These regional changes in BMD and bone architecture result in sublesional osteoporosis (SLOP) and an increased lifetime propensity for lower extremity fragility fracture when compared to their age and gender matched non-SCI peers [13]. Approximately 25$46 \%$ of $\mathrm{SCl}$ individuals develop lower extremity fragility fractures[14-19] Plausible risk factors for development of SLOP after SCI include: hormonal changes [20-22], immobility [23], abnormalities in blood circulation [24 25], autoimmune reactions, vitamin $D$ deficiency, low calcium intake and inadequate nutrition.

Nutrition plays a key role in the pathogenesis, prevention and treatment of osteoporosis in the aging able-bodied (Non-SCl) population with primary and secondary osteoporosis [26-32]. Nutrients essential for maintaining bone health include protein, calcium, phosphorous, magnesium, potassium, and copper, and vitamins $\mathrm{C}, \mathrm{D}$ and $\mathrm{K}$. Amongst these nutrients, calcium by far is the most important dietary constituent for 
maintaining bone mass [27 33]. Excessive intakes of animal protein, dietary fiber, free fatty acids, caffeine and phosphorus may possibly have adverse effects on bone mass, by decreasing calcium absorption. Studies have shown a strong correlation between bone mass and calcium intake across all age groups of the ablebodied population [33-37]. Individuals with long term inadequate calcium intakes have low bone mass and are at risk of developing osteoporosis [37]. An optimal calcium intake is thought to prevent osteoporosis development and to be a key component of osteoporosis treatment for all ages within the ablebodied population [33-37]. To ensure adequate calcium intake, both the Dietary Reference Intakes (DRIs) and Osteoporosis Canada (OC) recommend a calcium intake of $1000 \mathrm{mg}$ of calcium per day for men and women aged 19 to 50 years, and $1200 \mathrm{mg}$ calcium per day for individuals aged over 51 years of age [38 39].

There are many myths and considerable clinical equipoise regarding the ideal calcium intake acutely, sub-acutely (after discharge from inpatient rehabilitation), and long term ( $>2$ years post injury) after SCI. In order to prevent SLOP among individuals with $\mathrm{SCl}$, an adequate but not excessive intake of calcium and other nutrients relating to bone health are recommended. There are currently no evidence based recommendations for calcium intake after $\mathrm{SCl}$. There is little evidence describing how much calcium individuals with $\mathrm{SCl}$ require. To date, five studies have investigated the dietary calcium intake of patients with chronic SCI [40-44] However, their generalizability is limited by the relatively small sample sizes [40 44] and restriction of the sample to young active paraplegic men [41 42]. Recently, the inadequate dietary intakes among men and women with chronic $\mathrm{SCl}$ among a large sample of Ontarians was reported [43]. They reported that the mean usual intakes of vitamin $D$ and calcium were well below the DRI recommendation for adult men and women. Although the study did not include a non-SCl comparator group, it was methodologically rigorous. Understanding the current intake of calcium and other bone health related nutrients of people after $\mathrm{SCl}$ is the first step in beginning to formulate dietary prescriptions and nutritional interventions for the prevention and treatment of the SLOP after SCI.

The aims of this study were to: 1) describe and compare the intakes of bone health related nutrients including calcium of individuals with traumatic $\mathrm{SCl}$ with a cohort of age, gender and weight matched non-SCl peers; and 2) contrast the participants' intakes of bone health related nutrients with the north American dietary reference intakes (DRIs) parameters. We hypothesized that nutrient intakes in subjects with $\mathrm{SCl}$ would be insufficient compared with the non-SCl peers since people with $\mathrm{SCl}$ would have limited ability to shop and prepare meals.

\section{METHOD}

\section{Participants}

Participants included 87 consenting adults, aged 18-68 years, with acute or chronic traumatic SCI C1T10, AIS A-D affiliated with the SCl in- or outpatient services at Toronto Rehab, Lyndhurst Centre. Thirty paraplegics and 57 tetraplegics, mean $\mathrm{SCl}$ duration of $9.1 \pm 5.6$ years, were recruited via a poster campaign and $\mathrm{SCl}$ program staff. Eighty-five participants without $\mathrm{SCl}$, aged 18-66 years matched for age, gender and where possible BMI, were recruited as the control participants from the staff at Lyndhurst Centre, and friends of the authors. The study data were collected between January and October 1999.

Participants were given a brief description of the purpose of this study, and asked to provide written informed consent prior to completing the study procedures. Participants did not receive remuneration. $\mathrm{SCl}$ participant weight was measured using a Stathmos-Lindell self-indicating platform scale (Model 513-417, Stathmos Scale Manufacturing Limited, Milliken, $\mathrm{ON}$ ). $\mathrm{SCl}$ participants were instructed to wear light clothing and no shoes. Weight of the able-bodied non-SCl participants and heights of all participants were self-reported. This study was approved by the Research Ethics Board of Toronto Rehab, and we certify that all applicable institutional and governmental regulations concerning the ethical use of human volunteers were followed.

\section{Interview}

The 24-hour recall was administered on one occasion by a Registered Dietitian (EL or $A B$ ) The interview lasted 30-45 minutes. During the 24-hour recall, participants were probed to report all foods and beverages consumed as part of a meal and/or snack, as well as food preparation methods and brand names (where possible), in the previous 24 hours. Portion sizes were reported in household measures. Calcium, other nutrients and energy intakes from the 24-hour recall were calculated using Fuel Nutrition Software (version 2.1, 1998, Sillery, Quebec, Canada), updated with the 1997 Canadian Nutrient File. 
Total energy intake, macronutrients (protein, fat and carbohydrate), and selected micronutrient intakes (vitamin C, calcium, phosphorous, magnesium, potassium, iron, and sodium) were assessed. Each participant's dietary values were compared with the dietary reference intakes (DRIs) [38] to assess whether their intakes were appropriate. The measured nutrient intakes were compared with the DRIs. For the DRl's, the estimated average requirement (EAR), the adequate intake $(\mathrm{AI})$, the tolerable upper intake level (UL) and the acceptable macronutrient distribution range (AMDR) were used. EAR is the value set to meet the needs of $50 \%$ of individuals in a group. It is usually used to assess the adequacy of population intake. EAR was used as the reference value for determining adequacy of the protein, carbohydrate, Vitamin C, magnesium, phosphorus, and iron intakes. Al is the value set to meet the needs of almost all (97 to $98 \%$ ) of individuals in a group. Thus, Al is a higher and stricter threshold than EAR. The Al value was used to assess the adequacy of participant intake of calcium and potassium because these nutrients do not have an established EAR. The UL is the maximal level of daily nutrient intake unlikely to pose any risk of adverse effects. The UL was used for the phosphorus and sodium intakes because they inhibit the absorption of calcium if their intakes are excessive. AMDR is the range of intake for the particular energy source that is associated with risks of the chronic disease while providing intakes of essential nutrients for the macronutrient energy. The AMDR was used as the adequate energy range from protein, fat and carbohydrate. Intakes of vitamins $D$ and $E$ are not reported due to incomplete food composition data.

The DRIs for calcium (Al value) were assumed to be the age-gender ideal daily calcium intake [38]; $1000 \mathrm{mg} /$ day for $19-50$ year olds and $1200 \mathrm{mg} /$ day for those $>51$ years of age. A priori, $67 \% \mathrm{Al}$ for calcium intake $(670 \mathrm{mg}$ for $19-50 \mathrm{yrs}, 1005 \mathrm{mg}$ for $51-70 \mathrm{yrs}$ ) was defined as the minimum requirement for dietary calcium intake.

\section{Analysis}

All analyses were gender specific. Additionally, for the analysis of calcium intake, each gender was divided into three age categories (19-30yrs, 31-50yrs, 51-68yrs).

Descriptive data and selected nutrients were presented as the mean and standard deviation for each group. The percentage of participants who did not meet the recommendation of DRIs parameters was also described. The calcium intake was presented as the mean and range for each age and impairment group. The percentage of participants consuming less than both the $\mathrm{Al}$ and minimum requirement $(67 \% \mathrm{Al})$ calcium intake were also described. Quintiles were used for categorization of participants by calcium intake level.

The mean values of demographic data, daily energy intake, macronutrients and selected nutrients were compared between individuals with and without $\mathrm{SCl}$ using the $t$-test. Calcium intake in paraplegics and tetraplegics was also compared using the $t$-test. Twoway analysis of variance (ANOVA) was used to assess the effect of age (19-30yrs, 31-50yrs, 51-68yrs) and impairment status ( $\mathrm{SCl}$, Non-SCl) on calcium intake. A significance level of $p<0.05$ was used.

\section{RESULTS}

Demographic characteristics of the participants are displayed in Table 1. There were no significant differences in age, weight and $\mathrm{BMI}$ between the $\mathrm{SCl}$ and non-SCI participants, nor was there a difference in the between group distribution of men and women. Daily intakes of energy, macronutrients and selected nutrients relevant to calcium absorption are described in Table 2. There were no significant differences between the $\mathrm{SCl}$ and non-SCl participants, with the exception of the vitamin $C$ intake (Table 2). The percentage of participants not meeting the recommended intakes of energy, macronutrients and selected micronutrients relevant to bone health amongst the $\mathrm{SCl}$ and the non-SCl participants is reported (Table 3). Most participants met the recommended calorie intake for protein, fat and carbohydrate and the recommended amounts of protein carbohydrate, phosphorus and iron (Table 3). In non-SCl men, the percentage of participants with an excessive calorie intake from fat and a deficient calorie intake from carbohydrate was higher ( $29 \%$ versus $25 \%$, respectively) than those in the $\mathrm{SCI}$ men. In all groups, a majority of participants did not meet the recommended intakes of calcium (48$73 \%)$, magnesium $(40-55 \%)$, and potassium $(71-95 \%)$ (Table 3). The majority, 60 to $70 \%$ of participants consumed excessive amounts of sodium with the exception of non-SCl women (Table 3). There was a tendency toward a lower percentage of participants with insufficient vitamin $C$ intake in the male and female $\mathrm{SCl}$ participants versus non-SClpeers.

The ANOVA showed no significant effects of age (men: $p=0.581$, women: $p=0.977$ ) or impairment (men: 
Table 1: Demographic Characteristics of SCI and Non-SCI Participants

\begin{tabular}{|c|c|c|c|c|}
\hline \multirow{2}{*}{ Variables } & \multicolumn{2}{|c|}{ Men } & \multicolumn{2}{|c|}{ Women } \\
\hline & $\mathrm{SCl}(\mathrm{n}=66)$ & Non-SCI $(n=65)$ & $S C I(n=21)$ & Non-SCI $(n=20)$ \\
\hline \multicolumn{5}{|c|}{ Demographic variables (Mean+SD) } \\
\hline Weight (kg) & $74.9 \pm 14.6$ & $80.0 \pm 14.0$ & $62.2 \pm 10.9$ & $67.2 \pm 13.7$ \\
\hline BMI $\left(\mathrm{kg} / \mathrm{m}^{2}\right)$ & $23.5 \pm 4.2$ & $25.6 \pm 3.9$ & $22.7 \pm 4.3$ & $24.6 \pm 5.1$ \\
\hline Paraplegia & $22(33.3)$ & - & $8(38.1)$ & - \\
\hline Tetraplegia & $44(66.7)$ & - & $13(61.9)$ & - \\
\hline
\end{tabular}

SCI: spinal cord injury participants, Non-SCl; gender age-matched able bodied peers.

Table 2: Daily Intakes of Energy, Macronutrients and Micronutrients Relevant to Bone Health and Percentage of DRI Recommendations

\begin{tabular}{|c|c|c|c|c|c|}
\hline \multirow{2}{*}{ Nutrient } & & \multicolumn{2}{|c|}{ Men } & \multicolumn{2}{|c|}{ Women } \\
\hline & & SCI & Non-SCI & $\mathrm{SCl}$ & Non-SCI \\
\hline Total energy (kcal) & & $2468 \pm 813$ & $2406 \pm 735$ & $1925 \pm 545$ & $1833 \pm 451$ \\
\hline \multirow{2}{*}{ Protein } & Intake (g) & $95.7 \pm 34.4$ & $104.7 \pm 38.8$ & $80.1 \pm 24.3$ & $79.4 \pm 25.4$ \\
\hline & $\% \operatorname{EAR}(\%)$ & $(202 \pm 89)$ & $(202 \pm 80)$ & $(197 \pm 59)$ & $(186 \pm 70)$ \\
\hline$\%$ Kcal from protein & Intake (\%) & $15.5 \pm 3.1$ & $17.7 \pm 4.6$ & $16.9 \pm 3.1$ & $17.4 \pm 3.6$ \\
\hline Total Fat & Intake (g) & $76.8 \pm 36.1$ & $83.7 \pm 42.3$ & $60.6 \pm 24.9$ & $60 \pm 19.8$ \\
\hline \multirow{2}{*}{$\%$ Kcal from fat } & Intake (\%) & $27.5 \pm 7.4$ & $30.3 \pm 8.9$ & $28 \pm 6.5$ & $29.3 \pm 7.1$ \\
\hline & AMDR (\%) & $(20-35)$ & $(20-35)$ & $(20-35)$ & $(20-35)$ \\
\hline Carbohydorate & Intake (\%) & $355.5 \pm 109.4$ & $305.4 \pm 90.9$ & $268 \pm 79.7$ & $273.5 \pm 71.1$ \\
\hline \multirow{2}{*}{ Calcium } & Intake (mg) & $941.4 \pm 658.5$ & $904.3 \pm 458.3$ & $1006 \pm 414$ & $939.1 \pm 486.4$ \\
\hline & \%Al (\%) & $(91 \pm 62)$ & $(87 \pm 45)$ & $(96 \pm 40)$ & $(90 \pm 47)$ \\
\hline \multirow{2}{*}{ Vitamin C } & Intake (mg) & $232.8 \pm 147.9^{*}$ & $168 \pm 131.3$ & $246.1 \pm 110.4^{*}$ & $129.9 \pm 112.6$ \\
\hline & \%EAR (\%) & $(310 \pm 197)$ & $(224 \pm 175)$ & $(410 \pm 184)$ & $(242 \pm 188)$ \\
\hline \multirow{2}{*}{ Magnesium } & Intake (mg) & $345.8 \pm 129.5$ & $368.8 \pm 140$ & $328.3 \pm 117.8$ & $304 \pm 117$ \\
\hline & \%EAR (\%) & $(99 \pm 35)$ & $(106 \pm 39)$ & $(123 \pm 45)$ & $(116 \pm 45)$ \\
\hline \multirow{2}{*}{ Phosphorus } & Intake (mg) & $1439 \pm 528$ & $1456 \pm 622$ & $1259 \pm 389$ & $1248 \pm 464$ \\
\hline & \%EAR (\%) & $(251 \pm 107)$ & $(248 \pm 91)$ & $(217 \pm 69)$ & $(215 \pm 80)$ \\
\hline Potassium & Intake (mg) & $3725 \pm 1315$ & $3683 \pm 1382$ & $3649 \pm 1098$ & $3116 \pm 1313$ \\
\hline
\end{tabular}

SCl: spinal cord injury participants, Non-SCl; gender age-matched able bodied peers.

Data are group mean \pm SD.

AMDR: Acceptable Macronutrient Distribution Ranges, EAR: Estimated Average Requirements, UL: Tolerable Upper Intake Levels, Al: Adequate Intake. " $\mathrm{p}<0.05$ vs Non-SCl group. 
Table 3: Percentage of Participants Not Meeting the DRIs Recommendations of Energy, Macronutrients and Selected Micronutrients Relevant to Bone Health

\begin{tabular}{|c|c|c|c|c|c|}
\hline & & \multicolumn{2}{|c|}{ Men } & \multicolumn{2}{|c|}{ Women } \\
\hline & & $\mathrm{SCl}(66)$ & Non-SCI (65) & $\mathrm{SCl}(21)$ & Non-SCI (20) \\
\hline & & $\%$ & $\%$ & $\%$ & $\%$ \\
\hline \multirow{2}{*}{$\%$ Kcal from protein } & $:<$ AMDR & 6 & 2 & 0 & 0 \\
\hline & $:>A M D R$ & 0 & 0 & 0 & 0 \\
\hline$\%$ Kcal from fat & : >AMDR & 12 & 29 & 10 & 10 \\
\hline \multirow{2}{*}{ \%Kcal from Carbohydrate } & $:<$ AMDR & 11 & 25 & 10 & 15 \\
\hline & : >AMDR & 14 & 3 & 5 & 0 \\
\hline Protein $(\mathrm{g})$ & $:<$ EAR & 3 & 3 & 5 & 0 \\
\hline \multirow{2}{*}{ Phosphorus (mg) } & $:<$ EAR & 0 & 6 & 0 & 5 \\
\hline & $:>U L$ & 0 & 0 & 0 & 0 \\
\hline Calcium (mg) & $:<\mathrm{Al}$ & 73 & 72 & 48 & 60 \\
\hline Potassium (mg) & $:<\mathrm{Al}$ & 71 & 75 & 85 & 95 \\
\hline Iron (mg) & $:<$ EAR & 2 & 2 & 5 & 15 \\
\hline Fiber $(\mathrm{g})$ & $:<67 \%$ Al & 0 & 0 & 0 & 0 \\
\hline Caffeine (mg) & & 0 & 0 & 0 & 0 \\
\hline
\end{tabular}

Table 4: Calcium Intake by Age Group for SCI Participants vs Non-SCI Participants

\begin{tabular}{|c|c|c|c|c|c|c|}
\hline \multicolumn{7}{|c|}{ Men } \\
\hline Age (yr) & \multicolumn{2}{|c|}{$\mathrm{SCl}(\mathrm{mg})$} & $\mathbf{n}$ & \multicolumn{2}{|c|}{ Non-SCI (mg) } & $\mathbf{n}$ \\
\hline $19-30$ & 870.4 & $(291.5-2870.1)$ & 21 & 909.4 & $(161.2-2443.6)$ & 23 \\
\hline $31-50$ & 933.8 & $(253.2-2447.0)$ & 33 & 900.4 & $(202.7-2240.6)$ & 28 \\
\hline $51-68$ & 1087.0 & $(225.3-3390.0)$ & 12 & 904.0 & $(273.1-1334.2)$ & 14 \\
\hline $19-30$ & 848.1 & $(123.7-1227.1)$ & 6 & 1159.8 & $(621.7-1695.7)$ & 5 \\
\hline $31-50$ & 1086.9 & $(342.3-1583.6)$ & 9 & 795.9 & $(282.3-1616.7)$ & 10 \\
\hline $51-68$ & 1038.5 & $(574.0-1749.5)$ & 6 & 1004.8 & $(511.6-1866.2)$ & 5 \\
\hline
\end{tabular}

$\mathrm{SCl}$ : spinal cord injury participants, Non-SCl; gender age-matched able bodied peers. Data are group mean (range).

$p=0.755$, women: $p=0.880$ ) on calcium intake (Table 4). The majority (63.6 to $85.7 \%$ ) of the men did not meet the recommended level of calcium intake regardless of age and impairment (Figure 1). Many women (66.7 and $80.0 \%$ of participants) in the $51-68 \mathrm{yrs}$ age group ( $\mathrm{SCl}$ and non-SCl) did not meet the $\mathrm{Al}$ level for calcium (Figure 1). There were no prominent differences in the proportion of $\mathrm{SCl}$ and non-SCl participants falling below the minimum calcium requirements $(67 \% \mathrm{Al})$, except for the women in the 31 - 


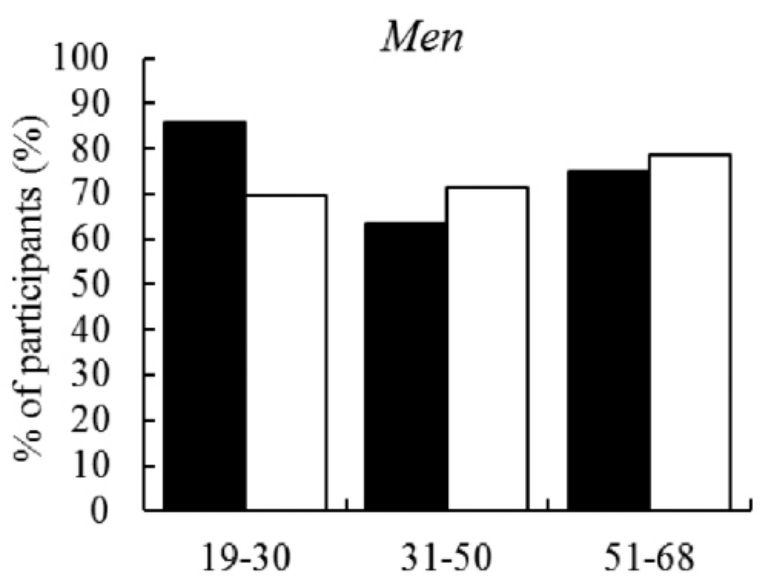

Age group (yr)

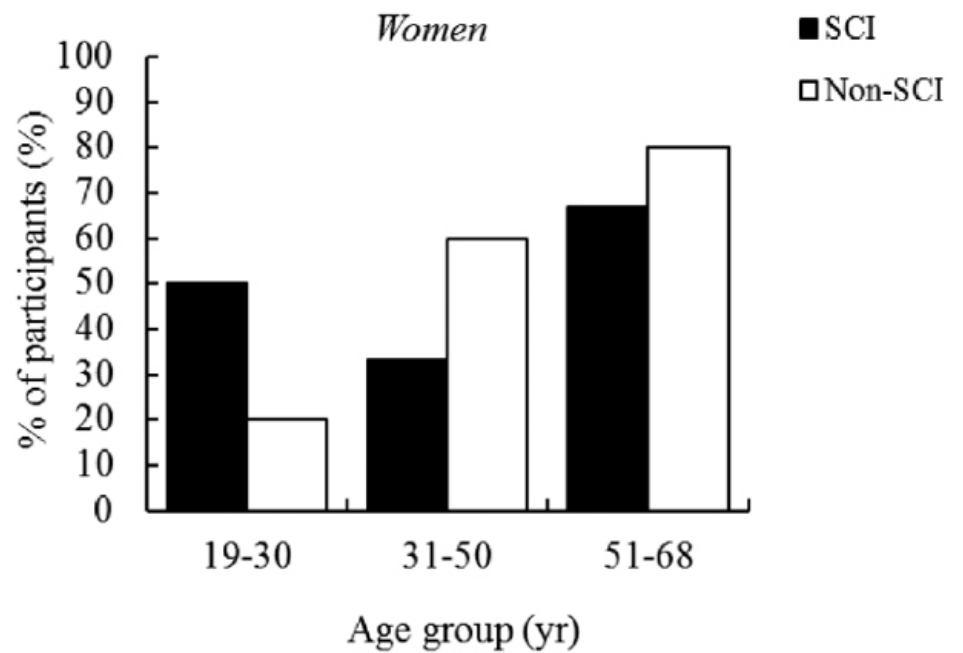

Figure 1: Percentage of participants consuming under the $\mathrm{Al}$ for calcium by age group for $\mathrm{SCl}$ and $\mathrm{Non}-\mathrm{SCI}$ participants.

50yr age groups (Figure 2). There was a tendency toward a higher proportion of participants with insufficient calcium intake in the male $\mathrm{SCl}$ participants versus able-bodied peers. Figure 3 illustrates the distribution of calcium intakes for the $\mathrm{SCl}$ and non-SCI participants. About two thirds (60\%) of all participants had a calcium intake of $<1000 \mathrm{mg}$ per day (SCl: $63.2 \%$, non-SCl: $66.1 \%)$. The majority of participants with $\mathrm{SCl}$ $(39.1 \%)$ and non-SCI (47.1) had calcium intakes of $>500$ and $\leqq 1000 \mathrm{mg}$ per day. It should be noted that about one quarter $(24.1 \%)$ of individuals with SCI had a calcium intake of $<500 \mathrm{mg}$ per day.

In Table 5, the calcium intake between paraplegic and tetraplegic participants was compared. There were no significant differences in the calcium intake between the two impairment groups.

\section{DISCUSSION}

We found that the levels of the calcium and other nutrient intakes of individuals with $\mathrm{SCl}$ were not significantly different from their age and gender matched, able-bodied controls. The majority of $\mathrm{SCl}$ and non-SCl participants did not meet the DRIs recommendation for calcium. In particular, the majority (63.6 to $85.7 \%$ of participants) of men did not meet the DRIs recommendation for calcium in all age and impairment groups. Additionally, a majority (66.7 and $80.0 \%$ of participants) of $51-68 \mathrm{yr}$ age women ( $\mathrm{SCl}$ and non-SCI) did not meet the DRIs recommendation. Moreover, it should be noted that the percentage of participants who consumed calcium below the minimum requirement $(<67 \% \mathrm{Al})$ was higher in $\mathrm{SCl}$ men compared with Non-SCl men across all age groups (Figure 2). Individuals with $\mathrm{SCl}$ have a much

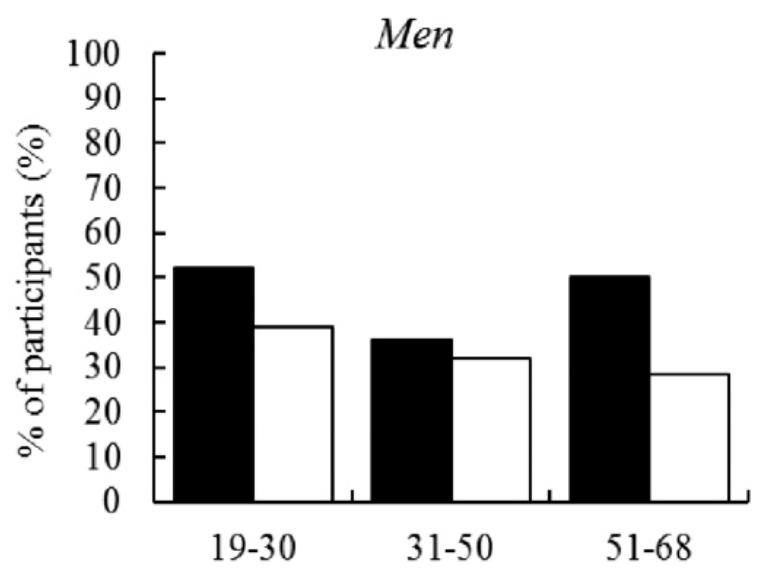

Age group (yr)

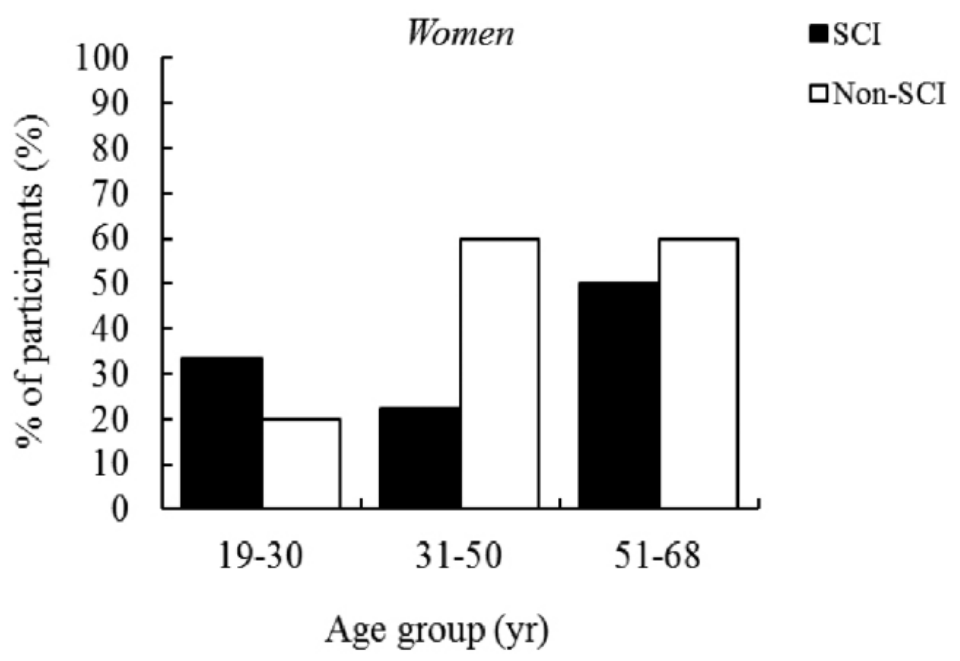

Figure 2: Percentage of participants consuming under $67 \% \mathrm{Al}$ for calcium by age group for $\mathrm{SCl}$ and Non-SCI participants. 


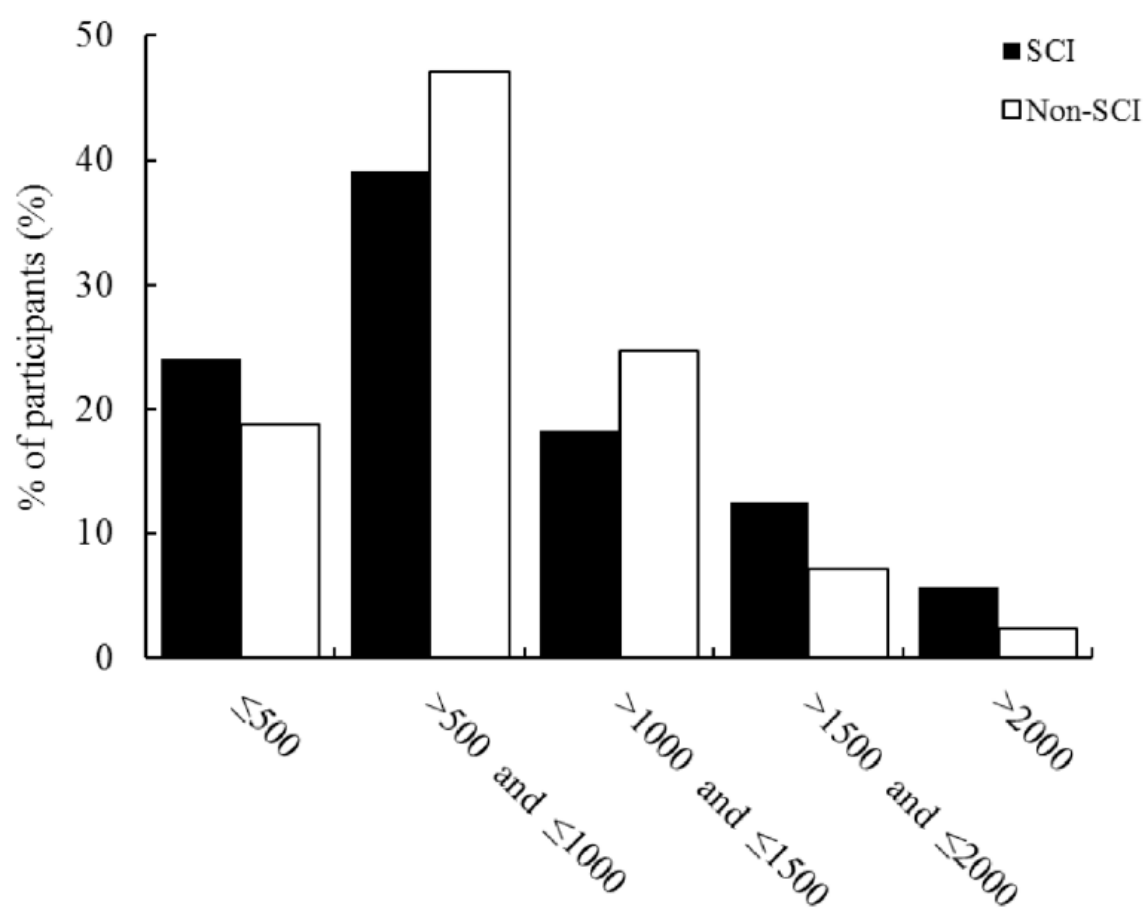

Calcium Intake (mg)

Figure 3: The distribution of $\mathrm{SCl}$ and Non-SCl participants to the classified calcium intakes.

Table 5: Comparison of the Calcium Intake between Paraplegic and Tetraplegic Participants and Percentage of Participants Consuming under the DRIs Recommendation (<Al value) and $<67 \% \mathrm{Al}$

\begin{tabular}{|c|c|c|c|c|}
\hline \multicolumn{5}{|c|}{ Men } \\
\hline & \multicolumn{2}{|c|}{ Calcium Intake (mg) } & $<\mathrm{Al}(\%)$ & $<67 \%$ Al (\%) \\
\hline Paraplegia $(n=22)$ & 972.4 & $(288.6-2447.0)$ & 72.7 & 36.4 \\
\hline Teraplegia $(n=44)$ & 926.0 & $(255.3-3390.0)$ & 72.7 & 50.0 \\
\hline \multicolumn{5}{|c|}{ Women } \\
\hline & \multicolumn{2}{|c|}{ Calcium Intake (mg) } & $<\mathrm{Al}(\%)$ & $<67 \%$ Al (\%) \\
\hline Paraplegia $(n=8)$ & 952.6 & $(574.1-1454.0)$ & 62.5 & 25.0 \\
\hline Teraplegia $(n=13)$ & 1037.0 & $(123.7-1749.5)$ & 46.2 & 38.4 \\
\hline
\end{tabular}

Calcium intake data are group mean (range).

higher risk of lower extremity fragility fractures and high fracture related mortality [45]. Therefore, they require lifestyle interventions to help prevent further declines in bone mass [46]. This is especially true in the 51-68yr age groups, which have a high risk of osteoporosis, greater incidence of fragility fractures, and the most insufficient calcium intakes.

Reports have indicated that a sufficient calcium intake prevents loss of bone mass in able-bodied individuals [33-37 47]. Baran et al. reported that premenopausal able-bodied women who had an average dietary calcium intake of $900 \mathrm{mg}$ lost bone mass from the lumbar spine at a rate of $1 \%$ per year, while the group supplemented with calcium intakes up to $1500 \mathrm{mg}$ a day, maintained their bone mass [34] . Dawson-Hughes et al. have indicated that dietary supplementation with calcium (500mg) and vitamin D (700IU) reduced bone loss over the three-year study period and reduced the incidence of non-vertebral fractures in men and women 65 years of age or older [47].

A calcium intake above the recommended level is not necessarily beneficial and may be harmful, while 
maintaining a sufficient intake is strongly recommended for able-bodied individuals. Osteoporosis Canada states that calcium is a threshold nutrient, i.e. the intake below a certain threshold level will result in a calcium deficiency, while increased calcium intake above the threshold level does not result in increased skeletal protection or benefit [48]. Therefore, it is suggested that calcium intake meets the recommended level. SCl individuals should be encouraged to maintain a sufficient intake of calcium; however, the DRIs are only available for able-bodied individuals. Excessive dietary calcium intake can precipitate renal or bladder stones post- $\mathrm{SCl}$ in persons with hypercalciuria or can exacerbate constipation [49-51]. Asymptomatic renal and bladder stones are frequently identified during routine renal and bladder ultrasounds or cystoscopy in patients with $\mathrm{SCl}$. Symptomatic stones present as shale or blood in the urine or as urosepsis and renal failure in the event of ureter obstruction [52]. Further investigation is necessary to determine the ideal calcium intake level for the $\mathrm{SCl}$ population.

Three previous studies reported the calcium intake among individuals with chronic SCI [40 42 43]. Walters et al. (2009) reported that the range of median calcium intakes across all age strata with $\mathrm{SCl}$ was 631.8$810.4 \mathrm{mg}$ and $631.8-873 \mathrm{mg}$ per day for men and women, respectively [43]. Levin et al. reported $550.0 \pm 268.3 \mathrm{mg}$ and $525.0 \pm 262.9 \mathrm{mg}$ per day for men and women with $\mathrm{SCl}$, respectively [40]. Tomey et al. reported $755 \pm 268.3 \mathrm{mg}$ per day for men with chronic $\mathrm{SCl}$ [42]. The participants in the present study had greater calcium intakes than reported previously (Men: 941.4 $\pm 658.5 .8 \mathrm{mg}$, Women: 1005.8 $\pm 414.0 \mathrm{mg}$ ). However, this difference was likely attributable to the male participants' lower energy intake. If the calcium intake is normalized per 1000 kilocalories, the differences in calcium intake become negligible (Walters: $352 \mathrm{mg} / 1000 \mathrm{kcal}$ [mean value of median values in all age group], Levine et al:: $327 \mathrm{mg} / 1000 \mathrm{kcal}$, Tomey et al:: $332 \mathrm{mg} / 1000 \mathrm{kcal}$, the present study: $377 \mathrm{mg} / 1000 \mathrm{kcal})$ among male participants. Additionally, Tomey et al. has reported that $43 \%$ of SCl men did not meet the minimum calcium requirements. This percentage was similar to that of the present study (49\%).

Calcium intake alone is insufficient to augment bone health, adequate intakes of other nutrients is also necessary. Other important nutrients for maintaining bone health include protein, phosphorous, magnesium, potassium, copper, vitamins C, D and K. Nutrients that should not be taken excessively include animal protein, dietary fiber, free fatty acids, caffeine and phosphorus. In the present study, we demonstrated that the total and percentage of energy macronutrient intakes and nutrient intakes are sufficient in both $\mathrm{SCl}$ and non- $\mathrm{SCl}$ participants. However, many participants in the $\mathrm{SCl}$ and non-SCl groups did not meet the recommended magnesium and potassium intake levels, and consumed excessive amounts of sodium. Previous studies have emphasized the importance of adequate dietary magnesium and potassium and low sodium intake to maintain or increase bone mineral density (BMD) [26 32]. Little research has been done regarding these nutrients in the $\mathrm{SCl}$ population [ [ $\left.\begin{array}{lll}40 & 42 & 43\end{array}\right]$. Regarding magnesium intake, these results concur with prior studies. Levine et al. have reported $217 \mathrm{mg}$ per day and $242 \mathrm{mg}$ per day magnesium intake, in $\mathrm{SCl}$ men and women, respectively [40]. These intakes appear lower than observed intakes in the present study, however when the magnesium intake is normalized (per 1000 kilocalories), the difference is minimal (Levine et al.: $129 \mathrm{mg} / 1000 \mathrm{kcal}$ in men, $188 \mathrm{mg} / 1000 \mathrm{kcal}$ in women, the present study: $143 \mathrm{mg} / 1000 \mathrm{kcal}$ in men, $173 \mathrm{mg} / 1000 \mathrm{kcal}$ in women). Walters et al. reported that the percentage of $\mathrm{SCl}$ men and women with magnesium intake below the EAR were $89 \%$ and $71 \%$, respectively [43]. These percentages were similar to the present study (Men: $71 \%$, Women: $85 \%$ ). With regards to potassium, the participants of the present study were higher than that of the previous studies (Men: $3728 \pm 1315 \mathrm{mg}$, Women: $3116 \pm 1313 \mathrm{mg}$ ). Levine et al. has reported $1975 \mathrm{mg}$ and $1828 \mathrm{mg}$ per day potassium intake, among SCI men and women, respectively [40]. Walters et al. reported that the range of the median calcium intakes across all age strata was $2399-2761 \mathrm{mg}$ for men and 2323$2703 \mathrm{mg}$ per day for women with chronic SCI [43]. The difference between the results of the present study and previous results remains similar after normalizing the values per 1000 kilocalories (Levine et al: $1378 \mathrm{mg} / 1000 \mathrm{kcal}$ in men, $1351 \mathrm{mg} / 1000 \mathrm{kcal}$ in women, Walter et al.: $1206 \mathrm{mg} / 1000 \mathrm{kcal}$ in men, $1488 \mathrm{mg} / 1000 \mathrm{kcal}$ in women [mean value of median values in all age group], the present study: $1582 \mathrm{mg} / 1000 \mathrm{kcal}$ in men, $1973 \mathrm{mg} / 1000 \mathrm{kcal}$ in women). Regarding the sodium intake, the participants of the present study consumed excessed sodium $(2949 \pm 1457 \mathrm{mg})$ as in the general Canadian population [53]. Additionally, the intakes in the present study were similar to previous reports in the $\mathrm{SCl}$ population. Walters et al. reported $2804 \mathrm{mg}$ sodium intake in the $\mathrm{SCl}$ men [mean value of median values in all age group] [43]. Tomey et al. reported $3058 \pm 1171.8 \mathrm{mg}$ sodium intake in their sample of $\mathrm{SCl}$ men with two 
thirds of participants consuming excess sodium [42]. Additionally, Levin et al. [40] reported that sodium intake in the SCl participants was $2594 \mathrm{mg}$ and $1949 \mathrm{mg}$ for men and women, respectively, which was less than we observed in prior reports from Walters et al and Tomey et al. Again, when the sodium intake is normalized per 1000 kilocalories, the differences become quite minimal (Levine et al.: $1569 \mathrm{mg} / 1000 \mathrm{kcal}$ in men, $1470 \mathrm{mg} / 1000 \mathrm{kcal}$ in women, Tomey et al:: $1348 / 1000 \mathrm{kcal}$ in men, the present study: 1243 $\mathrm{mg} / 1000 \mathrm{kcal}$ in men, $1528 \mathrm{mg} / 1000 \mathrm{kcal}$ in women). Together with these previous studies, the present study highlights the urgent necessity to educate individuals with $\mathrm{SCl}$ to improve their nutrient intake to facilitate calcium absorption and help maintain bone mass. Many individuals with $\mathrm{SCl}$ are dependent on others for assistance with grocery shopping and meal preparation. This may result in legitimate reason for their inappropriate dietary intake. Opperman et al. reported dietary supplement use in the $\mathrm{SCl}$ population [54]. They reported $20 \%$ of participants consumed a calcium supplement to maintain bone mass. For patients with insufficient calcium intakes, calcium absorption can be enhanced by taking supplements in divided doses, no more than $400-500 \mathrm{mg}$ at a time [13]. Given that the majority of people with $\mathrm{SCl}$ did not meet the recommended calcium intake and the fact 25 to $46 \%$ of persons living with chronic SCI develop lower extremity fragility fractures [14-19], more people with chronic SCl may need to try supplementation with calcium and bone related nutrients to ensure adequate nutrient intakes. However, it is known that calcium supplements increase the risk of nephrolithiasis and may cause mild gastrointestinal upset [55]. Additionally, although it is inconsistent and inconclusive, there is evidence that calcium supplements increase the risk of both coronary and cerebrovascular events [55].These conditions are already problematic and typically occur at an earlier age in individuals with $\mathrm{SCl}$ [56-58]. Clinicians and other healthcare providers, should promote adequate dietary calcium as a means to achieve the daily intake recommendation and reserve supplements for those who are unable or unwilling to achieve adequate dietary intake [55].

This study has limitations that require caution when interpreting and considering the generalizability of the findings reported herein. First, supplement use was not taken into account when calculating dietary intakes. Second, the vitamin $D$ intake of the participants was not assessed. Vitamin $D$ is an equally important nutrient as calcium with respect to bone health. Third, the nutrient analysis software (Fuel Nutrition Software, version 2.1, 1998, Sillery, Quebec, Canada) which was used for the data analysis is now out dated. However, although the software is now out dated, we believe that use of the old software is appropriate as it coincided with the average Canadian diet at the time of data collection. Fourth, although the 24 hour recall method was feasibie; a one-time nutrient assessment likely does not necessary reflect the complete spectrum of dietary habits. Therefore, it is not clear if the enclosed data is a fair representation of the subjects' dietary habits. The one week recall method for dietary assessment is a better option to evaluate subjects' dietary habits. Last, the influence of nutrient intakes and/or the urinary excretion of nutrients on actual bone health (i.e. bone density or fracture risk) were not assessed; nor were clinical risk factors for osteoporosis and fragility fracture including mobility status, physical activity level, alcohol intake, family history of fracture etc. recorded. Future prospective studies should try to relate the observed nutrient intakes to the subjects state of bone health.

\section{CONCLUSIONS}

Dietary calcium intake and selected nutrients relating to bone health after $\mathrm{SCl}$ were surveyed and compared with that of age-matched able-bodied non$\mathrm{SCl}$ individuals; both groups had equally insufficient nutrient intakes although their fracture risk is presumed to be quite different. A particular focus on individuals with $\mathrm{SCl}$ is needed due to their high risk of lower extremity fragility fractures. Similar to other authors, the present results revealed that nutrient intake insufficiency is prevalent among individuals with $\mathrm{SCl}$. As an adequate calcium intake is a prerequisite for bone health and many related pharmacologic treatments, we strongly recommend introduction of interventions to ensure adequate but not excessive intakes of bone health related nutrients, particularly among men with spinal cord injury.

\section{ACKNOWLEDGEMENT}

This study was funded by the Canadian Physiatry Research and Development Fund, Dr. Miyatani received salary supports from the Craig $\mathrm{H}$. Neilsen foundation (191150) and $\mathrm{Dr}$. Craven from the Toronto Rehabilitation Institute-UHN.

\section{REFERENCES}

[1] Demirel G, Yilmaz H, Paker N, Onel S. Osteoporosis after spinal cord injury. Spinal Cord 1998; 36(12): 822-5. http://dx.doi.org/10.1038/sj.sc.3100704 
[2] Freehafer AA, Hazel CM, Becker CL. Lower extremity fractures in patients with spinal cord injury. Paraplegia 1981; 19(6): 367-72. http://dx.doi.org/10.1038/sc.1981.69

[3] Lee TQ, Shapiro TA, Bell DM. Biomechanical properties of human tibias in long-term spinal cord injury. Journal of Rehabilitation Research and Development 1997; 34(3): 295302.

[4] Roberts D, Lee W, Cuneo RC, Wittmann J, Ward G, Flatman $R$, et al. Longitudinal study of bone turnover after acute spinal cord injury. J Clin Endocrinol Metab 1998; 83(2): 41522.

[5] Zehnder $\mathrm{Y}$, Luthi M, Michel D, Knecht H, Perrelet R, Neto I, et al. Long-term changes in bone metabolism, bone mineral density, quantitative ultrasound parameters, and fracture incidence after spinal cord injury: a cross-sectional observational study in 100 paraplegic men. Osteoporos Int 2004; 15(3): 180-9.

http://dx.doi.org/10.1007/s00198-003-1529-6

[6] Eser P, Frotzler A, Zehnder Y, Wick L, Knecht H, Denoth J, et al. Relationship between the duration of paralysis and bone structure: a pQCT study of spinal cord injured individuals. Bone 2004; 34(5): 869-80.

http://dx.doi.org/10.1016/. bone.2004.01.001

[7] Szollar SM, Martin EM, Parthemore JG, Sartoris DJ, Deftos LJ. Densitometric patterns of spinal cord injury associated bone loss. Spinal Cord 1997; 35(6): 374-82. http://dx.doi.org/10.1038/sj.sc.3100394

[8] Uebelhart D, Demiaux-Domenech B, Roth M, Chantraine A. Bone metabolism in spinal cord injured individuals and in others who have prolonged immobilisation. A review. Paraplegia 1995; 33(11): 669-73.

http://dx.doi.org/10.1038/sc.1995.140

[9] Pak CY, Oata M, Lawrence EC, Snyder W. The hypercalciurias. Causes, parathyroid functions, and diagnostic criteria. J Clin Invest 1974; 54(2): 387-400. http://dx.doi.org/10.1172/JCl107774

[10] Freeman LW. The Metabolism of Calcium in Patients with Spinal Cord Injuries. Annals of Surgery 1949; 129(2): 177-84. http://dx.doi.org/10.1097/00000658-194902000-00002

[11] Maimoun L, Couret I, Micallef JP, Peruchon E, MarianoGoulart D, Rossi M, et al. Use of bone biochemical markers with dual-energy $\mathrm{x}$-ray absorptiometry for early determination of bone loss in persons with spinal cord injury. Metabolism 2002; 51(8): 958-63.

http://dx.doi.org/10.1053/meta.2002.34013

[12] Stewart AF, Adler M, Byers CM, Segre GV, Broadus AE. Calcium homeostasis in immobilization: an example of resorptive hypercalciuria. N Engl J Med 1982; 306(19): 113640.

http://dx.doi.org/10.1056/NEJM198205133061903

[13] Craven LAR, McGillivray CF, Adachi JD. Detection and Treatment of Sublesional Osteoporosis Among Patients with Chronic Spinal Cord Injury. Topics in Spinal Cord Injury Rehabilitation 2009; 14(4): 1-22. http://dx.doi.org/10.1310/sci1404-1

[14] Eser P, Frotzler A, Zehnder Y, Denoth J. Fracture threshold in the femur and tibia of people with spinal cord injury as determined by peripheral quantitative computed tomography. Arch Phys Med Rehabil 2005; 86(3): 498-504. http://dx.doi.org/10.1016/i.apmr.2004.09.006

[15] Frisbie $\mathrm{JH}$. Fractures after myelopathy: the risk quantified. $\mathrm{J}$ Spinal Cord Med 1997; 20(1): 66-9.

[16] Ingram RR, Suman RK, Freeman PA. Lower limb fractures in the chronic spinal cord injured patient. Paraplegia 1989; 27(2): 133-9.

http://dx.doi.org/10.1038/sc.1989.20
[17] Lazo MG, Shirazi P, Sam M, Giobbie-Hurder A, Blacconiere MJ, Muppidi M. Osteoporosis and risk of fracture in men with spinal cord injury. Spinal Cord 2001; 39(4): 208-14. http://dx.doi.org/10.1038/sj.sc.3101139

[18] Ragnarsson KT, Sell GH. Lower extremity fractures after spinal cord injury: a retrospective study. Arch Phys Med Rehabil 1981; 62(9): 418-23.

[19] Vestergaard P, Krogh K, Rejnmark L, Mosekilde L. Fracture rates and risk factors for fractures in patients with spinal cord injury. Spinal Cord 1998; 36(11): 790-6. http://dx.doi.org/10.1038/sj.sc.3100648

[20] Bauman WA, Spungen AM, Flanagan S, Zhong YG, Alexander LR, Tsitouras PD. Blunted growth hormone response to intravenous arginine in subjects with a spinal cord injury. Horm Metab Res 1994; 26(3): 152-6. http://dx.doi.org/10.1055/s-2007-1000798

[21] Naftchi NE, Viau AT, Sell GH, Lowman EW. Pituitarytesticular axis dysfunction in spinal cord injury. Arch Phys Med Rehabil 1980; 61(9): 402-5.

[22] Shetty $K R$, Sutton $\mathrm{CH}$, Mattson DE, Rudman D. Hyposomatomedinemia in quadriplegic men. Am J Med Sci 1993; 305(2): 95-100.

http://dx.doi.org/10.1097/00000441-199302000-00006

[23] Vico L, Collet P, Guignandon A, Lafage-Proust MH, Thomas $\mathrm{T}$, Rehaillia $\mathrm{M}$, et al. Effects of long-term microgravity exposure on cancellous and cortical weight-bearing bones of cosmonauts. Lancet 2000; 355(9215): 1607-11. http://dx.doi.org/10.1016/S0140-6736(00)02217-0

[24] Bergmann P, Heilporn A, Schoutens A, Paternot J, Tricot A. Longitudinal study of calcium and bone metabolism in paraplegic patients. Paraplegia 1977; 15(2): 147-59. http://dx.doi.org/10.1038/sc.1977.20

[25] Chantraine A, van Ouwenaller C, Hachen HJ, Schinas P. Intra-medullary pressure and intra-osseous phlebography in paraplegia. Paraplegia 1979; 17(4): 391-9. http://dx.doi.org/10.1038/sc.1979.75

[26] Devine A, Criddle RA, Dick IM, Kerr DA, Prince RL. A longitudinal study of the effect of sodium and calcium intakes on regional bone density in postmenopausal women. Am J Clin Nutr 1995; 62(4): 740-5.

[27] Heaney RP. Bone mass, nutrition, and other lifestyle factors. Nutr Rev 1996; 54(4 Pt 2): S3-10.

[28] New SA, Robins SP, Campbell MK, Martin JC, Garton MJ, Bolton-Smith $\mathrm{C}$, et al. Dietary influences on bone mass and bone metabolism: further evidence of a positive link between fruit and vegetable consumption and bone health? Am J Clin Nutr 2000; 71(1): 142-51.

[29] Rude RK, Gruber HE. Magnesium deficiency and osteoporosis: animal and human observations. J Nutr Biochem 2004; 15(12): 710-6. http://dx.doi.org/10.1016/j.jnutbio.2004.08.001

[30] Sasaki S, Yanagibori R. Association between current nutrient intakes and bone mineral density at calcaneus in pre- and postmenopausal Japanese women. J Nutr Sci Vitaminol (Tokyo) 2001; 47(4): 289-94. http://dx.doi.org/10.3177/jnsv.47.289

[31] Schaafsma A, de Vries PJ, Saris WH. Delay of natural bone loss by higher intakes of specific minerals and vitamins. Crit Rev Food Sci Nutr 2001; 41(4): 225-49. http://dx.doi.org/10.1080/20014091091805

[32] Tucker KL, Hannan MT, Chen H, Cupples LA, Wilson PW Kiel DP. Potassium, magnesium, and fruit and vegetable intakes are associated with greater bone mineral density in elderly men and women. Am J Clin Nutr 1999; 69(4): 727-36.

[33] Reid IR, Ames RW, Evans MC, Gamble GD, Sharpe SJ. Effect of calcium supplementation on bone loss in postmenopausal women. N Engl J Med 1993; 328(7): 460-4. http://dx.doi.org/10.1056/NEJM199302183280702 
[34] Baran D, Sorensen A, Grimes J, Lew R, Karellas A, Johnson $\mathrm{B}$, et al. Dietary modification with dairy products for preventing vertebral bone loss in premenopausal women: a three-year prospective study. J Clin Endocrinol Metab 1990; 70(1): 264-70.

http://dx.doi.org/10.1210/jcem-70-1-264

[35] Dawson-Hughes B, Dallal GE, Krall EA, Sadowski L, Sahyoun N, Tannenbaum S. A controlled trial of the effect of calcium supplementation on bone density in postmenopausal women. N Engl J Med 1990; 323(13): 878-83. http://dx.doi.org/10.1056/NEJM199009273231305

[36] Prince RL, Smith M, Dick IM, Price RI, Webb PG, Henderson NK, et al. Prevention of postmenopausal osteoporosis. A comparative study of exercise, calcium supplementation, and hormone-replacement therapy. N Engl J Med 1991; 325(17): 1189-95. http://dx.doi.org/10.1056/NEJM199110243251701

[37] Welten DC, Kemper HC, Post GB, van Staveren WA. A meta-analysis of the effect of calcium intake on bone mass in young and middle aged females and males. J Nutr 1995; 125(11): 2802-13.

[38] Medicine lo. Dietary Reference Intakes: The Essential Guide to Nurient Requirements. Washington, DC: National Academy Press; 2006.

[39] Papaioannou A, Morin S, Cheung AM, Atkinson S, Brown JP, Feldman S, et al 2010 clinical practice guidelines for the diagnosis and management of osteoporosis in Canada: summary. CMAJ 2010; 182(17): 1864-73. http://dx.doi.org/10.1503/cmaj.100771

[40] Levine AM, Nash MS, Green BA, Shea JD, Aronica MJ. An examination of dietary intakes and nutritional status of chronic healthy spinal cord injured individuals. Paraplegia 1992; 30(12): 880-9. http://dx.doi.org/10.1038/sc.1992.165

[41] Ribeiro SML, da Silva RC, de Castro IA, Tirapegui J. Assessment of nutritional status of active handicapped individuals. Nutrition Research 2005; 25(3): 239-49. http://dx.doi.org/10.1016/j.nutres.2004.12.006

[42] Tomey KM, Chen DM, Wang X, Braunschweig CL. Dietary intake and nutritional status of urban community-dwelling men with paraplegia. Arch Phys Med Rehabil 2005; 86(4): 664-71.

http://dx.doi.org/10.1016/j.apmr.2004.10.023

[43] Walters JL, Buchholz AC, Martin Ginis KA. Evidence of dietary inadequacy in adults with chronic spinal cord injury. Spinal Cord 2009; 47(4): 318-22. http://dx.doi.org/10.1038/sc.2008.134

[44] Perret C, Stoffel-Kurt N. Comparison of nutritional intake between individuals with acute and chronic spinal cord injury. J Spinal Cord Med 2011; 34(6): 569-75. http://dx.doi.org/10.1179/2045772311Y.0000000026

[45] Carbone LD, Chin AS, Burns SP, Svircev JN, Hoenig H, Heggeness $\mathrm{M}$, et al. Mortality after lower extremity fractures in men with spinal cord injury. Journal of bone and mineral research: the official journal of the American Society for Bone and Mineral Research 2014; 29(2): 432-9.

http://dx.doi.org/10.1002/jbmr.2050
[46] Craven BC, Robertson LR, McGillivray CF, Bugaresti JM, Adachi JD. Treatment of Sublesional Osteoporosis Among Patients with SCl: A Proposed Treatment Paradigm. Topics in Spinal cord injury rehabilitation 2009; 14(4): 1-22.

http://dx.doi.org/10.1310/sci1404-1

[47] Dawson-Hughes B, Harris SS, Krall EA, Dallal GE. Effect of calcium and vitamin $\mathrm{D}$ supplementation on bone density in men and women 65 years of age or older. $\mathrm{N}$ Engl $\mathrm{J}$ Med 1997; 337(10): 670-6.

\section{http://dx.doi.org/10.1056/NEJM199709043371003}

[48] Murray TM. Prevention and management of osteoporosis: consensus statements from the Scientific Advisory Board of the Osteoporosis Society of Canada. 4. Calcium nutrition and osteoporosis. Cmaj 1996; 155(7): 935-9.

[49] Baker MJ, Longyhore DS. Dietary calcium, calcium supplements, and the risk of calcium oxalate kidney stones. American journal of health-system pharmacy: AJHP: official journal of the American Society of Health-System Pharmacists 2006; 63(8): 772-5. http://dx.doi.org/10.2146/ajhp050410

[50] Moyad MA. Calcium oxalate kidney stones: another reason to encourage moderate calcium intakes and other dietary changes. Urologic nursing 2003; 23(4): 310-3.

[51] Chen Y, DeVivo MJ, Stover SL, Lloyd LK. Recurrent kidney stone: a 25-year follow-up study in persons with spinal cord injury. Urology 2002; 60(2): 228-32. http://dx.doi.org/10.1016/S0090-4295(02)01734-X

[52] Kuhlemeier KV, Lloyd LK, Stover SL. Long-term followup of renal function after spinal cord injury. The Journal of urology 1985; 134(3): 510-3.

[53] Garriguet D. Sodium consumption at all ages: Statistics Canada - Health Reports, Vol 18, No 22007.

[54] Opperman EA, Buchholz AC, Darlington GA, Martin Ginis KA, Group S-SR. Dietary supplement use in the spinal cord injury population. Spinal Cord 2010; 48(1): 60-4. http://dx.doi.org/10.1038/sc.2009.86

[55] Bauer DC. The calcium supplement controversy: now what? Journal of bone and mineral research: the official journal of the American Society for Bone and Mineral Research 2014; 29(3): 531-3.

http://dx.doi.org/10.1002/jbmr.2184

[56] Garshick E, Kelley A, Cohen SA, Garrison A, Tun CG, Gagnon D, et al. A prospective assessment of mortality in chronic spinal cord injury. Spinal cord 2005; 43(7): 408-16. http://dx.doi.org/10.1038/sj.sc.3101729

[57] Phillips WT, Kiratli BJ, Sarkarati M, Weraarchakul G, Myers $\mathrm{J}$, Franklin BA, et al. Effect of spinal cord injury on the heart and cardiovascular fitness. Current problems in cardiology 1998; 23(11): 641-716. http://dx.doi.org/10.1016/S0146-2806(98)80003-0

[58] DeVivo MJ, Shewchuk RM, Stover SL, Black KJ, Go BK. A cross-sectional study of the relationship between age and current health status for persons with spinal cord injuries. Paraplegia 1992; 30(12): 820-7. http://dx.doi.org/10.1038/sc.1992.158 